\title{
EL ESQUEMA ARGUMENTAL DEL PSEUDOLUS Y SU RELACIÓN CON EL FOLKLORE*
}

\author{
Vicente Cristóbal López
}

Es nuestro propósito poner aquí de relieve las coincidencias entre el esquema argumental de una comedia plautina, el Pseudolus, que bien puede considerarse como representativa y arquetípica del género de la paliata, y el correspondiente, según los análisis de V. Propp ', a los cuentos populares llamados «maravillosos» que él así define: «género de cuentos que comienza con una disminución o un daño causado a alguien (rapto, expulsión del hogar, etc.), o bien con el deseo de poseer algo (el rey envía a su hijo a buscar el pájaro de fuego) y se desarrolla a través de la partida del protagonista del hogar paterno, el encuentro con un donante que le ofrece un instrumento encantado o un ayudante por medio del cual halla el objeto de su búsqueda» ${ }^{2}$.

No en vano ambos géneros, comedia y cuento, de génesis y profundo arraigo en las capas populares, habian por fuerza de coincidir en sus estructuras y en la modelación de sus personajes, por más que su forma de presentación, su transmisión y su grado de literaturización les hagan diferentes.

En efecto, ya como primer punto en común a destacar ( $y$ en ello no cabe hacer distingos entre comedia antigua y nueva), la prosopopeya del héroe cómico ${ }^{3}$ es, en general, la misma que la del héroe de los

* Este trabajo fue leído como comunicación en la Segunda Reunión Gallega de Estudios Clásicos (Santiago, septiembre de 1984).

1 Véanse su Morfología del cuento, Madrid, 1977, Ed. Fundamentos, y sus Raices históricas del cuento, Madrid, 1974, Ed. Fundamentos.

2 Raices historicas del cuento, p. 17.

3 Cf. J. L. Navarro González, "La estructura interna del héroe cómico», CFC, XV, 1978, pp. 137-166. 
cuentos: ambas obedecen a unos condicionamientos sociológicos determinados y determinantes: el pueblo, o el autor que al pueblo se dirige, proyecta en estos tipos su realidad y su deseo, o la realidad y el deseo del público a quien se dirige, a saber, su inferioridad en la jerarquía social, por una parte, y su aspiración revolucionaria, por otra, y así el héroe cómico y folklórico es siempre alguien que no destaca por su poder, fuerza o primacía, sino por su astucia, y que a pesar de su apariencia banal, insignificante y domeñada, es finalmente el triunfador; suelen ser los personajes más relegados socialmente los que, a la postre, prevalecen sobre los más encumbrados: las mujeres de Atenas arrebatan el poder a sus maridos, el leno y el viejo verde adinerado son derrotados y arrinconados por el esclavo astuto y el joven sin recursos - así en las comedias-, o bien - en los cuentos- el enano ingenioso supera al gigante forzudo, el hijo más pequeño del rey resulta más dotado y vencedor, por tanto, de sus otros dos hermanos mayores, Pulgarcitos y $\mathrm{Ca}$ perucitas se imponen a ogros carnívoros y lobos feroces. Lo que puede considerarse como fundamental en la conformación de ambos tipos heroicos es, pues, la paradoja entre su bajeza aparente y su triunfo final, bien que como diferencia entre ambos quepa señalar el mayor anclaje en la realidad histórica del héroe cómico con respecto al héroe de los cuentos, que vive una existencia más intemporal y fantástica.

Otro importante punto en común a destacar, sin duda el más evidente, es el happy end de uno y otro género, consecuencia del triunfo del héroe, que a su vez viene coronado y exaltado en uno y otro caso por la celebración convival o la francachela báquica. El tema del banquete final es constante en la comedia; y en los cuentos populares, la tan conocida fórmula «fueron felices y comieron perdices» (puesto que muy frecuentemente la victoria del protagonista coincide con su boda con la princesa) nos parece remontarse al mismo tema: banquete como manifestación de júbilo y felicidad conseguida ${ }^{4}$.

Pero adentrémonos ya en el análisis comparativo que nos proponemos. Los cuentos maravillosos comenzaban, según Propp, con una situación de carencia o de aspiración; un «héroe» debe partir en busca de un objeto; en su empresa cuenta con la colaboración de un «donante» que le proporciona un «objeto mágico» o «ayudante» la meta ulterior a las pruebas que ha de superar es a menudo el matrimonio con la «princesa»; en sus pretensiones ha de prevalecer el héroe sobre un «falso héroe» y superar la resistencia del "agresor» que le separa de la muchacha. Pues bien, el esquema argumental típico de la comedia nueva y de la paliata ( $\mathrm{y}$ en buena medida también de la novela, ya sea por influen-

4 Sobre los orígenes del tema del banquete, según aparece en la comedia, en rituales festivos, cf. F. Rodríguez Adrados, Fiesta, comedia y tragedia, Barcelona, 1972, Ed. Planeta, pp. 159 ss. y 398 y ss. 
cia de la comedia, ya por dependencia del flolklore mismo) se reduce al de dichos cuentos. Jóvenes sin recursos como héroes, esclavos y parásitos como ayudantes y donantes, militares fanfarrones como falsos héroes, doncella esclavizada como dueña amada y jefes de lupanar o padres ariscos como agresores: tales son los tipos primarios que componen su entramado ${ }^{5}$.

El argumento del Pseudolus plautino - comedia, por cierto, cuya fuente griega no nos es conocida- se acopla bien al esquema antedicho, y es como sigue, recordémoslo: un joven, Calidoro, quiere rescatar a su amada Fenicia de las garras del leno Balión, quien exige veinte minas como precio por la muchacha; Calidoro no puede comprarla por el momento, pero cuenta con los fieles servicios de su sagaz esclavo Pséudolo, que con sus fingimientos consigue por fin hacerse con la muchacha, tras engañar al criado del militar Polimaqueroplagides, dispuesto también a comprarla.

Patente es, pues, la situación inicial de carencia por parte del héroe: distanciamiento de su amada y falta de medios para conseguirla (salus argentea, v. 46).

El reparto de personajes de la comedia es equiparable al elenco de los tipificados por Propp para los cuentos ${ }^{6}$ :

- Contamos con un «héroe» en la persona de Calidoro, que con su indigencia inicial y su triunfo último revive la paradoja de que antes hablábamos, consustancial asimismo del héroe del cuento, aunque en su caso concreto más valiera dejarle con el título simple de «joven» y trasladar la heroicidad a su esclavo Pséudolo que es el que lleva todo el peso de la acción y el mérito de su feliz acabamiento.

- Contamos, por tanto, en la persona de Pséudolo con un heroico «ayudante» y «donante» al mismo tiempo, puesto que presta pri-

${ }^{5}$ Falta, sin embargo, en la comedia nueva y paliata (no asi en la novela) un elemento que era cardinal en los cuentos: el viaje del héroe, su traslado al *reino lejanow en busca del kobjeto mágico*, subsanador de la situación de carencia; este viaje solía realizarse en los cuentos (cf. Propp, Raices..., pp. 295 ss.) a lomos de un animal prodigioso. Y dicha falta no tanto debe achacarse a razones de representabilidad, pues que el viaje fantástico aparecía de modo palmario en $\mathrm{La}$ Paz de Aristófanes: Trigeo sube al cielo cabalgando sobre un gigantesco escarabajo en busca de la Paz, cuya ausencia tortura a sus conciudadanos atenienses. El motivo de tal ausencia habría que buscarlo en una peculiaridad inherente al género renovado: la comedia nueva, a la vez que circunscribe sus temas a la esfera de la vida privada, marginándose de la pública, se libera también de aquella carga de fantasía e idealidad que era ingrediente básico de la comedia aristofánica. Sobre la conjunción y equilibrio de lo real y lo ideal en esta última, cf. J. S. Lasso de la Vega, *Realidad, idealidad y política en la comedia de Aristófanes», CFC, IV, 1972, pp. 9-89.

Morfología..., pp. 91-92. 
mero sus servicios al joven y posteriormente le hace entrega de algo imprescindible («objeto mágico») para lograr su objetivo, la carta signada con el sello del militar, que hace innecesaria una gran parte de la suma del dinero solicitado para la compra ${ }^{7}$. Él es el verdadero protagonista y quien da título a la comedia, caracterizado por su capacidad de engaño y artimañas, comparado más de una vez con el astuto Ulises. Comparte con el mismo joven al que sirve, pero de manera más plena que él, la insignificancia a nivel social y la falta de medios materiales para comprar sus deseos, elementos que sirven de contraste a la fuerza de su ingenio y a su culminante victoria. Incluso por su apariencia físisca es un ser que desmiente la estampa del triunfo: «Individuo pelirrojo, barrigón, de gruesas piernas, tirando a negro, cabeza grande, ojos vivarachos, cara colorada, enormes pies" (vv. 1.218-1.220).

- La figura del leno Balión asumiría simultáneamente las funciones propias del «mandatario», pues él es quien impone a Calidoro la prueba de traer el dinero como requisito para comprar a Fenicia, y, en cierto modo, de «agresor» como más destacado oponente a las pretensiones del héroe.

- La función propia del «falso héroe» la asume - aunque sin aparecer en escena; sólo se le nombra, actuando en su lugar su esclavo Rapaz- el soldado fanfarrón, como rival del héroe con idénticas pretensiones que él: adueñarse de Fenicia, que es la figura correspondiente a la «princesa» de los cuentos.

- Unas cuantas máscaras más se subordinan a las anteriores, que son las principales: el esclavo Rapaz de Polimaqueroplagides, «ayudante» del «falso héroe»; el padre de Calidoro, Simón, que asumiría funciones propias del «agresor», puesto que se opone a la empresa de Pséudolo y de su hijo; el benévolo Califón, intercesor ante Simón a favor de su hijo Calidoro, que representaría una forma más de «ayudante» del «héroe», lo mismo que Carino, amigo y auxiliar del joven; Momo, el individuo que, compinchado con Pséudolo, se finge embajador del soldado ante Balión

\footnotetext{
7 Cf. vv. 117-118:

Ca.- Dabisne argenti mi hodie viginti minas?

Ps.- Dabo; ne molestus nunciam ne sis mihi...

y vv. 704-706:

Ps.-...Quaero quoi ter trina triplicia tribus modis tria gaudia artibus tribus ter demeritas dem laetitias de tribus fraude partas, per malitiam, per dolum et fallaciam; in libello hoc opsignato ad te hoc attuli pauxillulo.
} 
y que podría ser definido como «ayudante» del «ayudante»; añádase a ellos el cocinero contratado por el leno y su recua de pinches, que ninguna otra función cumplen sino la de distensión en la trama principal.

Este análisis pone de relieve las concomitancias entre el argumento del Pseudolus y el esquema argumental típico de los cuentos maravillosos, y tal es únicamente su virtud; salvo en la terminología con que definimos la esfera de funciones de cada personaje, coincide aproximadamente en todo lo demás con el esquema de relaciones diseñado por García Calvo para esta misma comedia plautina ${ }^{8}$.

Queda claro, pues, cómo las funciones de las distintas máscaras concuerdan en buena parte con las de los personajes de los cuentos. La única peculiaridad que ofrece el argumento del Pseudolus con respecto al esquema-prototipo del relato folklórico es la relevancia y protagonismo que se concede a la figura del «ayudante». Tal recurso, que salta a la vista igualmente en una obra tan insigne de nuestra literatura como es La Celestina, no es único ni siquiera en Plauto: en Curculio y en Epidicus tenemos igual engrandecimiento de la figura del esclavo auxiliar del joven, cuya actuación se constituye en protagonismo hasta el punto de dar nombre a la pieza. Pero incluso en el ámbito de los cuentos folklóricos hallamos, como en la obra plautina, un ejemplo ilustre de tal desviación con respecto al esquema argumental típico: $E l$ gato con botas (Le Maistre chat ou Le chat botté), cuento popular recogido en la colección de Perrault, presenta de nuevo un traslado de protagonismo del héroe a su ayudante:

- El ayudante es un animal, como suele ocurrir en los cuentos -recuérdense las hormigas o los pájaros que ayudan, respectivamente, a Psique y a Cenicienta a superar la prueba de la selección de semillas-, pero está caracterizado, igual que el esclavo de Calidoro, por su astucia, marrullería y arte de la falsificación: bien le cuadraría también al gato el nombre de Pséudolo. Es él quien, robando su palacio al proteico ogro tras haberse deshecho de él con engaño previo, hace creer al rey que aquella lujosa mansión pertenece a su amo, el presunto marqués de Carabás, en realidad un miserable molinero, como también le había hecho creer que los ropajes del marqués le habían sido robados mientras se bañaba, y que los extensos campos en que faenaban los segadores no eran sino propiedad de su amo.

× Plauto, Pseúdolo o Trompicón, Madrid, 1971, Ed. Cuadernos para el diálogo, pp. 8-15. 
- Toda la actuación del gato tiene por secuela el matrimonio del molinero-marqués con la princesa. El desheredado hijo de la fortuna se ve así encumbrado hasta lo impensable por obra de su artimañero ayudante, no de otro modo que Calidoro con respecto a Pséudolo.

- Ambos argumentos comenzaban con la situación angustiada del joven ${ }^{9} \mathrm{y}$, ante ella, la promesa de una ayuda ${ }^{10}$. Y ambos argumentos concluyen felizmente con la necesidad subsanada, la unión de los amantes y el banquete («magnifique colation que l'ogre avoit fait preparer pour ses amis» en El gato).

Sea esto suficiente para mostrar las vinculaciones que existen entre comedia y folklore. Sobre el porqué de tales vinculaciones, más que en orígenes rituales comunes nos inclinamos a pensar -como al principio apuntábamos - en comunes condicionamientos sociológicos y psicológicos de público y ambiente en que se gestan ambos géneros e incluso en un aprovechamiento de arquetipos folklóricos por parte de los autores cómicos. Son estas cuestiones genéticas, por lo demás, paulo maiora y exceden los límites de este trabajo.

"Cf. Pseud. 13: Misere miser sum, Pseudole!; Le chat: “...et le plus jeune n'eut que le chat. Ce dernier ne pouvoit se consoler d'avoir un si pauvre lot...n

10) Cf. Pseud. 103-105:

Verum ego te amantem, ne pave, non deseram.

Spero alicunde hodie me bona opera aut hoc meam

tibi inventurum esse auxilium argentarium;

Le chat: «Ne vous affligés point, mon maistre; vous n'avez qu'à me donner un sac et me faire faire une paire de bottes pour aller dans les brousailles, et vous verez que vous n'êtes pas si mal partagé que vous croyez.» 